\title{
Accelerated shelf-life test (ASLT) of batuan [Garcinia binucao (Blanco) Choisy] fruit powder
}

\author{
1,* Ancheta, A.K.G., ${ }^{2}$ Yaptenco, K.F., ${ }^{3}$ Mopera, L.E., ${ }^{3}$ Bainto, L.C., ${ }^{3}$ Lizardo, R.C.M. and \\ ${ }^{3}$ Dizon, E.I. \\ ${ }^{1}$ Department of Engineering Science, College of Engineering and Agro-Industrial Technology, University of \\ the Philippines Los Baños, Laguna, Philippines \\ ${ }^{2}$ Institute of Agricultural and Biosystems Engineering, College of Engineering and Agro-Industrial \\ Technology, University of the Philippines Los Baños, Laguna, Philippines \\ ${ }^{3}$ Institute of Food Science and Technology, College of Agriculture and Food Science, University of the \\ Philippines Los Baños, Laguna, Philippines
}

\author{
Article history: \\ Received: 15 January 2020 \\ Received in revised form: 14 \\ March 2020 \\ Accepted: 17 March 2020 \\ Available Online: 17 April \\ 2020
}

\section{Keywords:}

Accelerated shelf-life test, Garcinia binucao,

Color,

Non-enzymatic browning, Whiteness index

DOI:

https://doi.org/10.26656/fr.2017.4(4).018

\begin{abstract}
The study evaluated the storage characteristics of batuan fruit powder by Accelerated Shelf-life Test (ASLT) where the product was stored at elevated temperatures of $37^{\circ} \mathrm{C}$, $50^{\circ} \mathrm{C}$, and $60^{\circ} \mathrm{C}$. During the experiment, the physicochemical (whiteness index, $\mathrm{pH}$, total soluble solids, titratable acidity) and sensory (color, aroma, off-odor, general acceptability) characteristics of the product were monitored. The kinetics of nonenzymatic browning (NEB) was found to be a pseudo-first-order reaction in terms of whiteness index (WI). The effect of temperature on the rate constant for NEB was observed to follow Arrhenius Law such that the activation energy is $105.9 \mathrm{~kJ} \mathrm{~mol}^{-1}$ and $Q_{10}$ is 3.90 . The shelf-life of the product at room temperature was predicted to be 202 days (6.7 months).
\end{abstract}

\section{Introduction}

In the Philippines, tamarind is considered as the most popular souring agent used in dishes such as sinigang. However, due to the dramatic increase in population, the supply of locally available tamarind is no longer sufficient to meet the consumer demand (Valencia, 2013a; Reyes, 2000). Due to the huge market of tamarind in the country, the Philippines is continuously importing tamarind to meet the domestic needs (Mojica, 2008), hence, an alternative souring agent should be considered.

Nowadays, researchers realized the importance of underutilized crops and their conversion into high-value products to feed more than 100 million Filipinos (Florido and Cortiguerra, 2003; Valencia, 2013b; Ebert, 2014). Batuan fruit is a Philippine indigenous underutilized crop that is popular in the Bicol and Visayas regions as a substitute to tamarind as a souring agent. A study by Quevedo et al. (2013) revealed the potential of using batuan as a souring agent. Aside from being acidic, the fruit is also found to be safe for consumption and rich in fiber, vitamins $\mathrm{A}$ and $\mathrm{C}$, and minerals. Thus, batuan is indeed a promising alternative souring agent that addresses both sensory and nutritional needs.

Although batuan fruit is abundant, it is a seasonal fruit and is available only from April to June. Therefore, there is a need to preserve this fruit to lengthen its shelflife and to make it available all year round. An effective way to preserve this fruit is to turn it into powder just like tamarind sinigang mix.

Though powdered products are shelf-stable, deteriorative reactions in food are inevitable that may lead to a decline in quality and spoilage. Shelf-life is the period during which the product maintains its quality and consumer acceptability. The consumer acceptability of a food product is a subjective judgment based on visual assessment followed by organoleptic assessment after manufacture. Therefore, shelf-life tests must include both subjective tests (i.e., taste, flavor, color, texture) and objective criteria (i.e., microbial growth, caking) (Taoukis et al., 1997; 1994; Koca et al., 2003; Jaya and Das, 2005; Patel et al., 2007).

To determine the shelf-life of a specific food 
product, Accelerated Shelf-life Test (ASLT) can be performed. Temperature values above $25^{\circ} \mathrm{C}$ are used during the experiment to accelerate the deterioration of the product. Thus, the shelf-life of a product can be determined in a relatively shorter time (i.e., 2 weeks) at elevated temperatures, whereas the actual shelf-life may be much longer (i.e., 1-2 years).

There are researches about the determination of shelf -life through ASLT done by Lee and Krotchta (2002) for whey-protein-coated peanuts where the peanuts were subjected to 3 temperatures of $40^{\circ} \mathrm{C}, 50^{\circ} \mathrm{C}, 60^{\circ} \mathrm{C}$ and storage time up to 31 weeks, and Patel et al. (2007) for sweetened condensed milk where the development of brown color (in terms of absorbance) was found to be a zero-order reaction; several studies about the kinetics of food degradation during storage were conducted by Burdurlu and Karadeniz (2003), Koca et al. (2003), Wang et al. (2005), and Valdramidis et al. (2009) for juices and concentrates, among others, where the brown color was measured in terms of absorbance at $420 \mathrm{~nm}$ and CIE-Lab color system, and browning was either zero -order or first-order reaction. However, very limited research or information has been found regarding the kinetics of deterioration and shelf-life of batuan fruit powder.

The shelf-life of fruit powders in air-tight containers are generally about 6 months, however, the selection of a predominant index of quality (i.e., color, moisture content, vitamin $\mathrm{C}$ content, flowability) varies depending on the nature of the food material. Guava fruit powder, for example, produced by grinding guava slices and packed in moisture-impermeable containers, takes 6 months before the ascorbic acid content becomes significantly low and the moisture content slightly increases (Hui, 2008). The shelf-life of mango powder is 105 days ( 3.5 months) using color as the index of quality (Jaya, 2005). Chang et al. (2018) reported that spraydried soursop powder packed in aluminum-laminated polyethylene (ALP) lasted for 91 days (3 months) before lumpiness was observed. Further research by Chang et al. (2019) revealed that soursop with $1 \%$ (w/w) tricalcium phosphate had an extended shelf-life up to 316 days (10.5 months). For spray-dried tamarind pulp powder, the shelf-life at accelerated storage condition was predicted to be 53 days ( 1.8 months) and 66 days (2.2 months) using ALP and 4-ply laminate, respectively, based on the flowability of the powder; the color change of the powder was also studied and was found to follow zero-order kinetics (Muzaffar and Kumar, 2017). Juan's Calamansi Powder ${ }^{\circledR}$, a spray-dried calamansi powder marketed by D-Lite Ingredients and Chemicals in Philippines, can be stored up to 24 months (Sanchez, 2012).
Hence, this study is aimed to determine if the shelflife of batuan fruit powder, a high-value product made from underutilized batuan fruit, can be predicted using ASLT based on a selected index of quality.

\section{Materials and methods}

\subsection{Source of batuan fruits}

Batuan fruits were obtained from a local market in Bacolod City, Philippines and then shipped to University of the Philippines Los Baños. The fruits used in the experiment had characteristic green color, hard covering, and medium to large size (about $3.7-5.5 \mathrm{~cm}$ in diameter) only.

\subsection{Production of batuan fruit powder}

\subsubsection{Preparation of frozen batuan fruits}

As soon as the fresh and immature (sourest among the different stages of maturity) batuan fruits were received, the fruits were washed initially with tap water to remove adhering contaminants, then, the whole fruits were disinfected by soaking in $10 \mathrm{ppm}$ hypochlorous acid $(\mathrm{HOCl})$ solution (about 1:1 by volume of fruit and solution, or enough to coat all the fruits with the solution) for $20 \mathrm{~s}$ to further decrease or eliminate its initial microbial load. The fruits were washed again in running potable water to remove excess chlorine in the fruits. Afterwards, the fruits were packed in PE bags (about $10 \mathrm{~kg}$ per bag) and then stored in a chest freezer at $-20^{\circ} \mathrm{C}$ to stop biochemical and microbial degradation of the fruits. Before processing into powder, the frozen fruits were thawed in running water for about 5 mins and drained well.

\subsubsection{Pre-drying treatments}

The whole fruits were steamed for 20 mins to inactivate the enzymes (i.e., browning enzymes such as oxidase) and to soften the pulp for easier removal by the pulping machine. After steaming, the cooked fruits were immediately cooled with running water to stop further heating. Then, the steamed fruits were fed in a pulping machine (fabricated in the Institute of Food Science and Technology, UPLB) to separate the seeds and recover the pulp. The recovered pulp was separated into three lots where each lot was treated with a predetermined amount of $10 \%$ sodium metabisulfite (SMS). SMS was added to the pulp so that the pulp would contain 106.25 ppm concentration which was determined as optimum SMS concentration from a preliminary study. The amount of SMS added in the product satisfied the permitted daily intake of SMS for humans which is 0.7 mg per kg of body weight (WHO, 1999). 


\subsubsection{Drying of batuan fruit pulp}

A cabinet dryer (fabricated in UPLB) was used to dry the pretreated samples. The pulp was laid on stainless steel trays layered with polyethylene to prevent the pulp from sticking onto the trays after drying. The thickness of the pulp on the trays was set at $3 \mathrm{~mm}$ maximum to allow faster drying. Drying temperature of $50^{\circ} \mathrm{C}$, which was determined as the optimum temperature during a previous experiment, was employed in the study. The sample was dried at $50^{\circ} \mathrm{C}$ for $48 \mathrm{hrs}$ until it reached a moisture content of $10.75 \%$. The dried pulp was scraped off the drying trays using a spatula.

\subsubsection{Grinding and sieving}

The dried pulp was pulverized using a grinder $\left(\mathrm{Koii}^{\circledR}\right.$ Platinum Edition, Koii Philippines) and then sieved using 60-mesh USA sieve. The powdered samples were immediately packed in glass bottles and were stored in desiccators at room temperature.

\subsection{Selection of index of quality for ASLT}

To assure the validity of the predicted shelf-life of batuan fruit powder using ASLT, the index of quality that should be used in modelling was carefully selected. In this study, several indices were screened for fitness in ASLT of the souring agent based on sensory attributes (color, aroma, off-odor, and general acceptability) and physicochemical characteristics (pH, TA, TSS, and WI).

\subsubsection{Sensory evaluation}

Sensory evaluation of the samples was done using Quality Scoring as performed by ten (10) semi-trained panelists. The parameters evaluated were color, aroma, off-odor, and general acceptability. The test used a 15$\mathrm{cm}$ line for each parameter with increasing intensity from left (score of 0 ) to right (score of 15). The color was assessed as "light brown" (0) to "dark brown" (15) with sample pictures showing standard colors of light brown and dark brown to the judges for reference. To evaluate aroma, from "weak" (0) to "strong" (15), a sample of fresh or puréed batuan fruit was used as a reference. Offodor was assessed from "not perceivable" (0) to "perceivable" (15). General acceptability was scored from "not acceptable" (0) to "acceptable" (15).

\subsubsection{Physicochemical and proximate analyses}

The batuan fruit powder samples were subjected to physicochemical analyses in terms of $\mathrm{pH}$, titratable acidity (TA), total soluble solids (TSS), and whiteness index (WI). The $\mathrm{pH}$ of the batuan fruit powder was determined by using a $\mathrm{pH}$ pen (Eutech ${ }^{\circledR}$ Instruments $\mathrm{pH}$ 2700, Eutech Instruments Pte. Ltd., Singapore) in a 1:9 by weight (dilution factor of 10) mixture of batuan powder and distilled water. The TA was determined following the methods by AOAC (2000). The TSS was analyzed by dissolving the batuan fruit powder in distilled water at a dilution factor of 10 , and the degree Brix $\left({ }^{\circ} \mathrm{Bx}\right)$ of the solution at $20^{\circ} \mathrm{C}$ was read using a refractometer (Cole-Parmer ${ }^{\circledR}$ Refractometer EW-8115032, Cole-Parmer Instrument Company LLC, USA). The WI was calculated given values of $L, a$, and $b$ (Bawar, 2013; Hsu et al., 2003; Tsai, 1994; Sheen, 1990):

$$
W I=100-\sqrt{(100-L)^{2}+a^{2}+b^{2}}
$$

$L$ (lightness), $a$ (redness), and $b$ (yellowness) were measured using a chromameter (X-Rite Capsure ${ }^{\circledR}$ RM200-PT01, X-Rite Inc., USA).

Proximate analysis (moisture content, ash, crude fat, crude fiber, crude protein, and total carbohydrates) was also conducted to characterize the batuan fruit powder. The method of AOAC (2000) was followed.

\subsection{Experimental setup for ASLT of batuan fruit powder}

The accelerated storage of batuan fruit powder was done by the modified procedure of Jaya and Das (2005) for mango powder. Twenty grams (20 g) of batuan fruit powder was packed in $13 \mathrm{~cm} \times 10 \mathrm{~cm}$ pouches, made of metallic foil. The packed powders were placed in incubators set at $37^{\circ} \mathrm{C}, 50^{\circ} \mathrm{C}$, and $60^{\circ} \mathrm{C}$. At $37^{\circ} \mathrm{C}$, the product was monitored every 5 days for 20 days. At $50^{\circ}$ $\mathrm{C}$, the product was checked for 20 days with a 4-day interval. At $60^{\circ} \mathrm{C}$, the product was observed every 3 days for 6 days. In addition, packages were prepared for storage at room temperature (approximately $29^{\circ} \mathrm{C}$ ) and in the freezer (about $-20^{\circ} \mathrm{C}$ ) to check if the deterioration of the product would happen at lower temperatures; at these temperatures, the pouches were sampled every week (Lee and Krotchta, 2002).

For every interval, a sample was analyzed of its physicochemical properties including WI, $\mathrm{pH}, \mathrm{TSS}$, and TA.

Sensory evaluation (by quality scoring) in terms of color, aroma, off-odor, and general acceptability was done every time interval to determine whether the changes in physicochemical properties were perceived by the panelists or not. The results were used to determine or decide on critical parameters (i.e., critical WI) that may be used to predict the shelf-life of the product at room temperature.

\subsection{Estimation of shelf-life of batuan fruit powder}

2.5.1 Determination of the rate constant, $k$, for each temperature, $T$

The rate constants were determined from the 
linearized plots of the parameters (i.e., WI) against time. The value of the regression coefficient, $R^{2}$, was also checked to determine the fitness of the linearized equations.

\subsubsection{Determination of $k$ at the storage temperature}

Using the linearized form of the Arrhenius equation, a plot of $T^{-1}$ (reciprocal of the absolute temperature in Kelvin) at the $x$-axis and $\ln k$ (natural logarithm of the rate constant) at the $y$-axis was done. From the slope and $y$-intercept, the pre-exponential factor, $k_{o}$, and the activation energy, $E_{a}$ (for each parameter) were determined. Then, by extrapolation, the value of $k$ at room temperature was estimated.

\subsubsection{Determination of shelf-life}

For each parameter, the critical value was identified such that beyond this value, the product was no longer acceptable. Then, the shelf-life was calculated by substituting the values in the kinetic model to determine $t$ which is the shelf-life.

In case that the shelf-life at a high-temperature $T_{1}$ was given, the shelf-life at room temperature $T_{2}$ was estimated given the rate constants at $T_{1}$ and $T_{2}$ for any reaction order (Lee and Krotchta, 2002).

$$
k_{1} t_{s 1}=k_{2} t_{s 2}
$$

Where $k_{1}, k_{2}=$ rate constants at $T_{1}$ and $T_{2}$, respectively; and $t_{s 1}, t_{s 2}=$ shelf-life values at $T_{1}$ and $T_{2}$, respectively

The room temperature when the ASLT was conducted (March 9-30, 2015) was about $29^{\circ} \mathrm{C}$ where the summer season had already started. However, to consider the storage of the product all-year-round, the room temperature was assumed to be equal to the annual average room temperature in Manila, Philippines which is $27.7^{\circ} \mathrm{C}$ (Average Temperatures in Manila, Luzon, Philippines, 2015). The basis for shelf-life was obtained from the sensory evaluation of the powder during ASLT such that the product was no longer acceptable or there was already a significant difference in the sensory attributes between the sample at $t=0$ and the sample at $t$ $=t_{s}$.

\subsection{Statistical analysis}

All analyses were done in triplicates. The determined values were expressed as mean \pm standard deviation (SD). Data were analyzed using one-way ANOVA to determine if the samples significantly differed from one another, followed by Tukey's HSD test to know which among the samples were significantly different. ANOVA and HSD were done using Statistical Analysis System ${ }^{\circledR}$ (SAS Version 9, SAS Institute Inc., USA) computer software at $5 \%$ level of significance.

\section{Results and discussion}

\subsection{Selection of index of quality for ASLT}

\subsubsection{Whiteness index}

Browning, especially non-enzymatic browning, may happen during storage of the product, thus, it was observed at varying temperature and time of storage. During sampling of the packed powders, the WI of the samples was monitored at predetermined time intervals. The WI of the powder changed from light brown to dark brown or even almost black at $60^{\circ} \mathrm{C}$. However, at room and freezing temperatures, there are negligible changes in WI. Hence, it is suggested to store the product at the temperature not higher than the room temperature.

The WI values of the powder are plotted in Figure 1. The temperature values above the room temperature reveal that WI decreases with the time of storage. The rate of decrease in WI increases with temperature as shown by steeper slopes of the curves. During the experiment, the decrease in WI was perceived as darkening in color from light brown to dark brown. However, at room and freezing temperatures, the change in color of the powder was negligible where the slopes of the graphs are nearly horizontal.

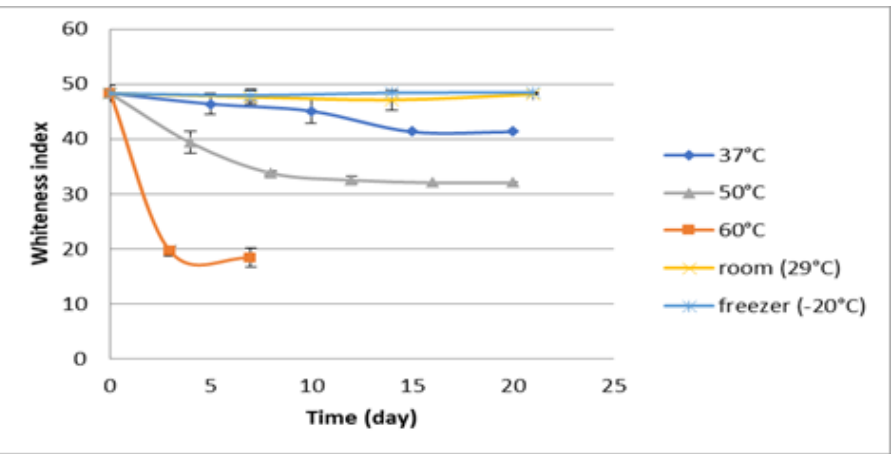

Figure 1. Plot of whiteness index against time for batuan fruit powder at varying temperatures. Samples were stored (a) at $37^{\circ} \mathrm{C}, 50^{\circ} \mathrm{C}$, and $60^{\circ} \mathrm{C}$ for accelerated shelf-life test, (b) at room temperature for reference, and (c) in the freezer to check the assumption that color never changed during cold storage. WI ranges from 0 to 100 where 100 means "perfect" white and lower values mean darker in color.

The browning of the batuan powder may be accounted to non-enzymatic browning such as Maillard browning, vitamin $\mathrm{C}$ oxidation, etc. The oxidation of the remaining vitamin $\mathrm{C}$ after heat processing would also contribute to browning. Based on the proximate analysis (Table 1), the powder contains $0.23 \%$ crude protein and $75.19 \%$ NFE (assumed to be carbohydrates) that are potential substrates to produce melanoidins (responsible for the development of brown color) after dehydration and storage at relatively high temperature. However, it is suggested in future researches to analyze for the presence of melanoidins in the product to verify the occurrence of Maillard browning. Moreover, there is a little chance that 
Table 1. Proximate composition of batuan fruit pulp and powder

\begin{tabular}{lcccc}
\hline \multirow{2}{*}{ Composition } & \multicolumn{2}{c}{ Wet basis (\%) } & \multicolumn{2}{c}{ Dry basis (g water/g solids) } \\
\cline { 2 - 5 } & Pulp & Powder & Pulp & Powder \\
\hline Moisture content & $87.15 \pm 0.10$ & $10.75 \pm 0.02$ & $6.785^{\mathrm{a}}$ & $0.121^{\mathrm{b}}$ \\
Ash & $0.32 \pm 0.02$ & $2.44 \pm 0.06$ & $0.025^{\mathrm{a}}$ & $0.027^{\mathrm{a}}$ \\
Crude protein & $2.81 \pm 0.07$ & $0.23 \pm 0.05$ & $0.219^{\mathrm{a}}$ & $0.003^{\mathrm{b}}$ \\
Crude fat & $1.84 \pm 0.52$ & $3.16 \pm 0.11$ & $0.144^{\mathrm{a}}$ & $0.035^{\mathrm{b}}$ \\
Crude fiber & $0.45 \pm 0.03$ & $8.23 \pm 0.11$ & $0.092^{\mathrm{a}}$ & $0.035^{\mathrm{b}}$ \\
NFE & 7.42 & 75.19 & 0.578 & 0.843 \\
\hline
\end{tabular}

Mean values with the same superscript within rows are not significantly different at $P \leq 0.05$, HSD.

enzymatic browning would happen due to the heat treatment applied that inactivated the enzymes present in the fruits.

\section{$3.1 .2 \mathrm{pH}$}

The $\mathrm{pH}$ values of the powder samples are summarized in Figure 2. The $\mathrm{pH}$ values generally increased slightly from about 1.6 and maintained at almost 1.9. The small increase in $\mathrm{pH}$ may be due to oxidation or volatilization of some of the organic acids present in the powder at high temperature (Chu and Clydesdale, 1976; Dursun et al., 2017). Nevertheless, all the $\mathrm{pH}$ values are not significantly different at $5 \%$ level of significance.

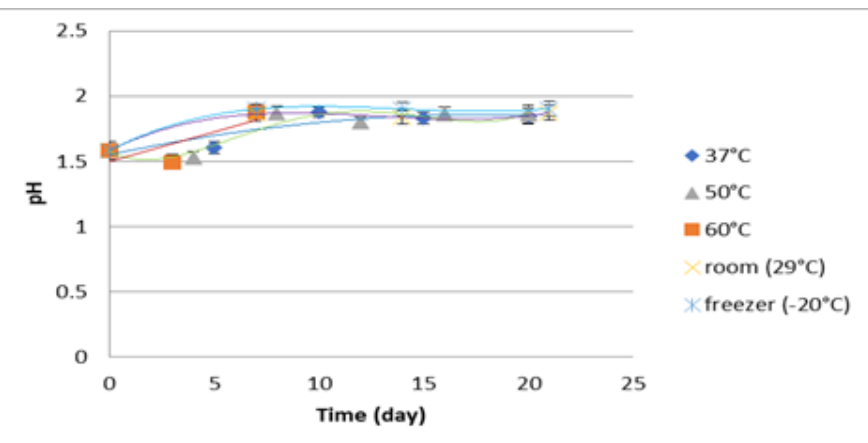

Figure 2. Plot of $\mathrm{pH}$ against time for batuan fruit powder at varying temperatures. Samples were stored (a) at $37^{\circ} \mathrm{C}, 50^{\circ} \mathrm{C}$, and $60^{\circ} \mathrm{C}$ for accelerated shelf-life test, (b) at room temperature for reference, and (c) in the freezer to check the assumption that $\mathrm{pH}$ never changed during cold storage.

\subsubsection{Total soluble solids (TSS)}

The TSS values observed (Figure 3) were higher than those of fresh pulp since drying results in the concentration of the soluble solids. The initial decrease in TSS during storage may be due to the utilization of sugars during non-enzymatic browning which was accelerated at higher temperatures (Buedo et al., 2000; Burdurlu and Karadeniz, 2003; Damasceno et al., 2008), whereas the slight increase towards the end may be due to the degradation of pectin (Fraeye et al., 2007). Based on statistical analysis, all the values of TSS are not significantly different from each other at $5 \%$ level of significance.

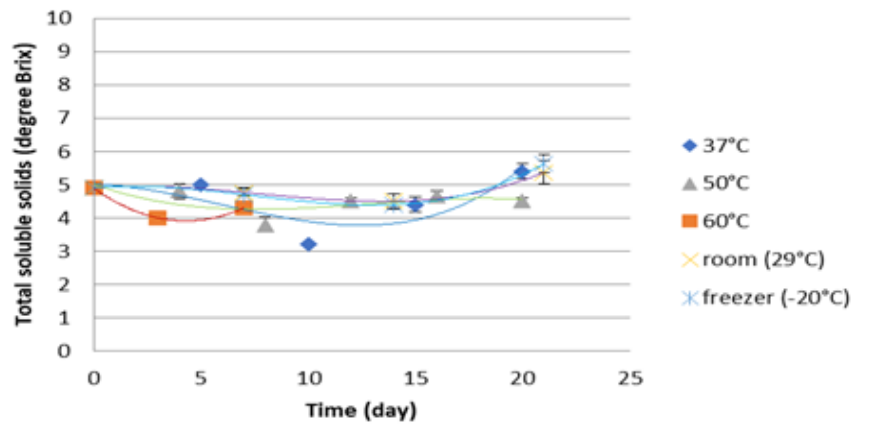

Figure 3. Plot of total soluble solids (TSS) against time for batuan fruit powder at varying temperatures. Samples were stored (a) at $37^{\circ} \mathrm{C}, 50^{\circ} \mathrm{C}$, and $60^{\circ} \mathrm{C}$ for accelerated shelf-life test, (b) at room temperature for reference, and (c) in the freezer to check the assumption that TSS never changed during cold storage.

\subsubsection{Titratable acidity (TA)}

The titratable acidity was calculated in terms of percent citric acid which is predominant in the sample. Although oversimplified, the computation of TA is only based on the predominant acid present which is citric acid even if there are several organic acids present such as oxalic acid, tartaric acid, malic acid, lactic acid, acetic acid, fumaric acid, succinic acid, and hydroxycitric acid (Quevedo et al., 2017; Bainto et al., 2018). Nevertheless, the values of TA in terms of percent by mass of citric acid against storage time are plotted in Figure 4.

For all temperatures, the TA values of the powder decreased as the time of storage progressed. There was a higher rate of decline of TA at higher storage temperatures as shown by steeper slopes, meaning, that the acids in the powder were more volatile at a higher temperature. Thus, heat and time during storage played a role in reducing the acid content of the powder (Chu and Clydesdale, 1976; Dursun et al., 2017).

Also, the heat treatment during processing resulted in a decrease in the amount of acids present in the powder (Bainto et al., 2018). By comparing the dry-basis values (g citric acid/g solids) of fresh batuan fruit pulp (0.4545) and batuan fruit powder (0.2994), the TA actually decreased after drying of the pulp due to 
volatilization of some of the acids during drying at $50^{\circ} \mathrm{C}$ for 48 hours.

Statistical analysis by ANOVA at 5\% level of significance revealed that, for each temperature setting, only the final value of TA is significantly different from the other values of TA.

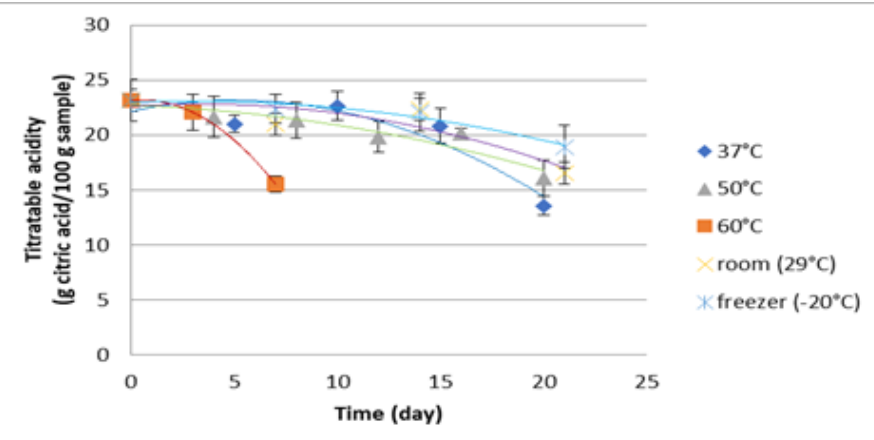

Figure 4. Plot of titratable acidity (TA) against time for batuan fruit powder at varying temperatures. Samples were stored (a) at $37^{\circ} \mathrm{C}, 50^{\circ} \mathrm{C}$, and $60^{\circ} \mathrm{C}$ for accelerated shelf-life test, (b) at stored at room temperature for reference, and (c) in the freezer to check the assumption that TA never changed during cold storage.

\subsection{Changes in sensory attributes of batuan fruit powder during ASLT}

The goal of sensory evaluation was to determine whether the physicochemical changes during accelerated storage were perceived by the panelists or not. The parameters for sensory evaluation are color, aroma, offodor and general acceptability (Table 2).

\subsubsection{Color}

The increase in mean scores with time implied that the degree of browning was perceived by the panelists where higher scores would mean darker brown color. At $37^{\circ} \mathrm{C}$, the panelists were not able to detect changes in color even up to 20 days of observation even if the chromameter showed a significantly different value of WI after 15 days. At $50^{\circ} \mathrm{C}$ (after 4 days) and $60^{\circ} \mathrm{C}$ (after 3 days), the significant change in color was already observed. Color change at lower temperatures (room at $29^{\circ} \mathrm{C}$ and freezer at $-20^{\circ} \mathrm{C}$ ) was insignificant.

\subsubsection{Aroma}

At $37^{\circ} \mathrm{C}$, there was no significant difference between the scores by the panelists. At $50^{\circ} \mathrm{C}$, the change in aroma was already perceived after 4 days of storage. At $60^{\circ} \mathrm{C}$,

Table 2. Mean scores of sensory attributes of batuan fruit powder during Accelerated Shelf-life Test

\begin{tabular}{cccccc}
\hline Temperature $\left({ }^{\circ} C\right)$ & Time $(\mathrm{d})$ & Color & Aroma & Off-odor & General acceptability \\
\hline & 0 & $1.15 \pm 0.59^{\mathrm{a}}$ & $4.84 \pm 0.01^{\mathrm{a}}$ & $3.33 \pm 0.39^{\mathrm{a}}$ & $10.44 \pm 0.08^{\mathrm{a}}$ \\
& 5 & $4.92 \pm 1.12^{\mathrm{a}}$ & $7.50 \pm 0.95^{\mathrm{a}}$ & $3.32 \pm 1.09^{\mathrm{a}}$ & $9.58 \pm .33^{\mathrm{a}}$ \\
& 10 & $2.54 \pm 0.14^{\mathrm{a}}$ & $6.74 \pm 0.57^{\mathrm{a}}$ & $1.75 \pm 0.08^{\mathrm{a}}$ & $9.90 \pm 0.56^{\mathrm{a}}$ \\
& 15 & $6.22 \pm 0.15^{\mathrm{a}}$ & $8.15 \pm 0.63^{\mathrm{a}}$ & $1.18 \pm 0.07^{\mathrm{a}}$ & $11.06 \pm 0.39^{\mathrm{a}}$ \\
& 20 & $3.40 \pm 0.13^{\mathrm{a}}$ & $5.80 \pm 0.08^{\mathrm{a}}$ & $1.85 \pm 0.59^{\mathrm{a}}$ & $8.92 \pm 1.34^{\mathrm{a}}$ \\
\hline \multirow{5}{*}{50} & 0 & $1.15 \pm 0.59^{\mathrm{a}}$ & $4.84 \pm 0.01^{\mathrm{a}}$ & $3.33 \pm 0.39^{\mathrm{a}}$ & $10.44 \pm 0.08^{\mathrm{a}}$ \\
& 4 & $5.00 \pm 0.37^{\mathrm{b}}$ & $8.44 \pm 0.07^{\mathrm{b}}$ & $4.53 \pm 0.74^{\mathrm{a}}$ & $10.98 \pm 0.45^{\mathrm{a}}$ \\
& 8 & $9.19 \pm 0.83^{\mathrm{b}}$ & $9.22 \pm 0.04^{\mathrm{b}}$ & $3.48 \pm 0.09^{\mathrm{a}}$ & $7.41 \pm 0.04^{\mathrm{ab}}$ \\
& 12 & $11.95 \pm 1.74^{\mathrm{b}}$ & $11.44 \pm 0.62^{\mathrm{b}}$ & $4.39 \pm 0.30^{\mathrm{a}}$ & $6.76 \pm 0.87^{\mathrm{b}}$ \\
& 16 & $11.33 \pm 0.21^{\mathrm{b}}$ & $8.02 \pm 0.96^{\mathrm{b}}$ & $2.70 \pm 0.04^{\mathrm{a}}$ & $6.95 \pm 0.22^{\mathrm{ab}}$ \\
& 20 & $11.89 \pm 0.83^{\mathrm{b}}$ & $7.80 \pm 1.33^{\mathrm{b}}$ & $2.95 \pm 0.40^{\mathrm{a}}$ & $6.00 \pm 0.57^{\mathrm{b}}$ \\
\hline \multirow{2}{*}{60} & 0 & $1.15 \pm 0.59^{\mathrm{a}}$ & $4.84 \pm 0.01^{\mathrm{a}}$ & $3.33 \pm 0.39^{\mathrm{a}}$ & $10.44 \pm 0.08^{\mathrm{a}}$ \\
& 3 & $14.55 \pm 0.54^{\mathrm{b}}$ & $9.84 \pm 0.51^{\mathrm{b}}$ & $6.45 \pm 0.30^{\mathrm{a}}$ & $3.47 \pm 0.14^{\mathrm{b}}$ \\
\hline \multirow{3}{*}{20 (freezer) } & 0 & $1.15 \pm 0.59^{\mathrm{a}}$ & $4.84 \pm 0.01^{\mathrm{a}}$ & $3.33 \pm 0.39^{\mathrm{a}}$ & $10.44 \pm 0.08^{\mathrm{a}}$ \\
& 7 & $3.65 \pm 1.22^{\mathrm{ab}}$ & $5.03 \pm 0.79^{\mathrm{a}}$ & $2.75 \pm 0.52^{\mathrm{a}}$ & $9.59 \pm 0.81^{\mathrm{a}}$ \\
& 14 & $2.71 \pm 0.04^{\mathrm{b}}$ & $7.38 \pm 0.38^{\mathrm{a}}$ & $1.43 \pm 0.08^{\mathrm{a}}$ & $9.97 \pm 0.40^{\mathrm{a}}$ \\
& 21 & $1.14 \pm 0.60^{\mathrm{a}}$ & $4.59 \pm 0.35^{\mathrm{a}}$ & $2.19 \pm 1.91^{\mathrm{a}}$ & $7.30 \pm 1.35^{\mathrm{a}}$ \\
\hline \multirow{5}{*}{29 (room) } & 0 & $1.15 \pm 0.59^{\mathrm{a}}$ & $4.84 \pm 0.01^{\mathrm{a}}$ & $3.33 \pm 0.39^{\mathrm{a}}$ & $10.44 \pm 0.08^{\mathrm{a}}$ \\
& 7 & $4.58 \pm 1.28^{\mathrm{a}}$ & $6.42 \pm 0.16^{\mathrm{a}}$ & $2.98 \pm 0.33^{\mathrm{a}}$ & $9.06 \pm 0.06^{\mathrm{a}}$ \\
& 14 & $3.62 \pm 0.51^{\mathrm{a}}$ & $8.22 \pm 1.03^{\mathrm{a}}$ & $1.15 \pm 0.04^{\mathrm{a}}$ & $10.96 \pm 0.05^{\mathrm{a}}$ \\
& 21 & $2.29 \pm 1.74^{\mathrm{a}}$ & $6.30 \pm 2.91^{\mathrm{b}}$ & $1.38 \pm 0.80^{\mathrm{a}}$ & $6.89 \pm 2.03^{\mathrm{a}}$ \\
\hline
\end{tabular}

Values of the same superscript per attribute are not significantly different at $P \leq 0.05$.

The mean values were obtained from 2 experiment runs and $N=10$ laboratory panelists.

Range of scores: Color: 0 - light brown, 15 - dark brown; Aroma: 0 - weak, 15 - strong; Off-odor: 0 - not perceivable, 15 perceivable; General acceptability: 0 - not acceptable, 5 - slightly acceptable, 10 - acceptable, 15 - very acceptable. 
strong aroma was recognized by the panelists after 3 days only. At room temperature, there was a significant increase in the quality score for aroma after 3 weeks of storage. In the freezer, no significant change in aroma was observed by the panelists. The sudden development of aroma may be accounted to a faster rate of NEB at higher temperature (Buedo et al., 2000; Lee and Shibamoto, 2002; Berlinet et al., 2006).

\subsubsection{Off-odor}

Changes in off-odor were not perceived by the panelists throughout the sampling period. The low scores showed that off-odor may not be perceivable even at $60^{\circ}$ $\mathrm{C}$ where the sudden change in odor was interpreted as aroma and not off-odor. Thus, there is low tendency for the powder to develop off-odor during storage within the given range of time and temperature tested.

\subsubsection{General acceptability}

During storage at $37^{\circ} \mathrm{C}$ and below for 3 weeks, the scores did not change significantly. However, at $50^{\circ} \mathrm{C}$, the product became less acceptable after 8 days of storage where the scores lie between slightly acceptable (5) and acceptable (10); the change in scores was negligible up to 20 days of storage, hence, the product remained acceptable even after 20 days. At $60^{\circ} \mathrm{C}$, after 3 days, the product was given a rating between unacceptable and slightly acceptable; at this point, the product may be at its critical condition where further storage may result in an unacceptable product. Hence, the general acceptability of the product decreases faster as the storage temperature increases.

\subsection{Kinetics of non-enzymatic browning of batuan fruit powder}

Based on the results of ASLT for several parameters, it may be concluded that color (in terms of WI) is the most important index of quality for batuan fruit powder because its change with time and temperature is highly pronounced based on statistical analysis.

The change in color was mathematically described using several predictive rate laws. The kinetics of nonenzymatic browning of batuan fruit powder was expected to be either pseudo-zero (linear) or pseudo-first (logarithmic) order based on previous studies in other food products. From Figure 1, it can be observed that the behavior of the curves is logarithmic and approaching a constant (or equilibrium) value for each temperature. Hence, a rate law for the browning of the powder is proposed such that the reaction order is 1 (pseudo-first order) and there is an equilibrium value of WI at a certain temperature.

$$
-\frac{d(W I)}{d t}=k\left(W I-W I_{e}\right)
$$

Where $W I=$ whiteness index, $t=$ time $(\mathrm{d}), k=$ rate constant $\left(\mathrm{d}^{-1}\right)$, assumed to be a function of temperature, and $W I_{e}=$ equilibrium whiteness index, dependent on the storage temperature

Upon integration, the equation becomes

$$
-\ln \frac{W I-W I_{e}}{W I_{0}-W I_{e}}=k t
$$

Where $W I_{o}$ is the initial whiteness index $(=48.30$ for batuan fruit powder). In Figure 5, a plot of $-\ln \frac{W I-W T_{e}}{W I_{0}-W T_{e}}$ against $t$ was generated for each accelerated

storage temperature where the slope is equal to the rate constant, $k$.

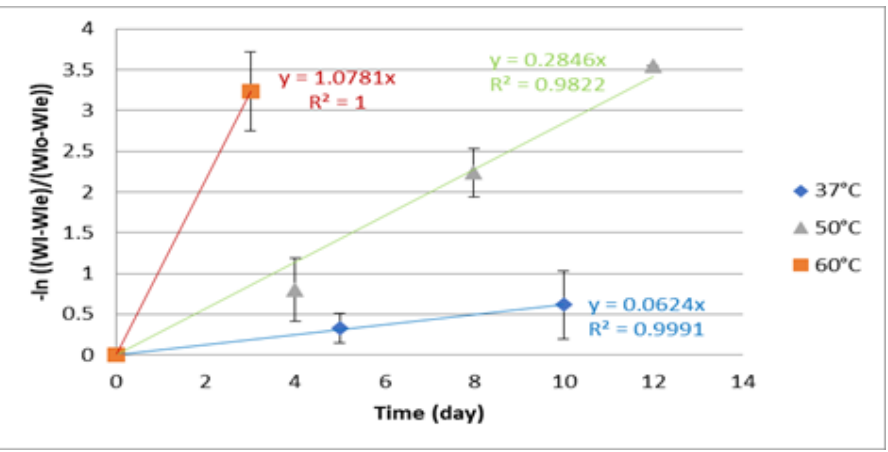

Figure 5. Linearized plots of whiteness index (WI) against time at varying temperatures. The last data point for each temperature was omitted because the $y$ value was actually "-ln (0)" which is undefined.

Figure 5 shows that there is a good fitness of the points as proven by high $R^{2}$ values $(0.9991,0.9822$, and $1)$. Therefore, the reaction order could be pseudo-first order $(n=1)$. Some studies such as Wang et al. (2005) for carrot juice concentrate, Damasceno et al. (2008) for cajuina during thermal processing, Ibarz et al. (2000) for apple purée, also revealed pseudo-first-order reactions for NEB. Wang et al. (2005) and Damasceno et al. (2008) used absorbance at $420 \mathrm{~nm}\left(A_{420}\right)$ to indicate the NEB of their samples. However, Ibarz et al. (2000) reported that although browning in terms of $A_{420}$ (absorbance at $420 \mathrm{~nm}$ ) follows a zero-order kinetics, the change in color in terms of lightness, $L$, is a first-order process; the same was observed in this study because the whiteness index is dependent on $L$ so that first-order NEB was also achieved. On the other hand, Burdurlu and Karadeniz (2003), and Koca et al. (2003) obtained zeroorder NEB for apple juice and citrus juice concentrates, respectively, where the index of browning is also $A_{420}$. Valdramidis et al. (2009) stated that for orange juice, NEB follows zero-order kinetics but the degradation of ascorbic acid, which also contributes to browning, is first order. Nevertheless, analysis of vitamin $\mathrm{C}$ is not recommended because of its low initial amount due to the series of heat treatments (i.e., steaming, cabinet 
drying) the batuan fruit went through. The untreated fruit pulp contains only $1.70 \mathrm{mg}$ ascorbic acid per $100 \mathrm{~g}$ fruit (dry basis) as reported by Quevedo et al. (2013) so that the powdered form might have lower vitamin $\mathrm{C}$ content.

\subsection{Determination of activation energy and $Q_{10}$ for $N E B$ of batuan fruit powder}

The activation energy, $E_{a}$, of the NEB of batuan fruit powder was determined by generating a linearized Arrhenius plot of rate constant against temperature. Calculations show that there is a high correlation $\left(R^{2}=\right.$ $0.9967)$ between the rate constant and temperature:

$$
\ln k=-12,732\left(\frac{1}{T}\right)+38.236
$$

The NEB was proven to be sensitive to temperature as observed by Kilic et al. (1997) in cheese powder. To obtain Arrhenius parameters, there should be at least 3 temperatures during the shelf-life test done under isothermal condition (Lee and Krotchta, 2002).

Hence, the linearized equation became useful in calculating the activation energy of the process. Therefore, the activation energy, obtained from the slope of the trend line, is equal to $105.9 \mathrm{~kJ} \mathrm{~mol}^{-1}(25.31 \mathrm{kcal}$ $\left.\mathrm{mol}^{-1}\right)$. This value is basically high compared to those obtained by Ibarz et al. (2000) for apple purée - $51.9 \mathrm{~kJ}$ $\mathrm{mol}^{-1}$, Burdurlu and Karadeniz (2003) for apple juice concentrates - 21.0-33.7 kcal mol ${ }^{-1}$, Koca et al. (2003) for citrus juice concentrates - 6.67-27.81 kcal mol${ }^{-1}$, and Kilic et al. (1997) for cheddar cheese powder $15.1-22.3 \mathrm{kcal} \mathrm{mol}^{-1}$. Higher activation energy means greater excess energy barrier needed to overcome to proceed to NEB of the powder (Taoukis et al., 1997). For batuan fruit powder, the high value of $E_{a}$ may imply difficulty of NEB to occur, given the packaging system of the powder, resulting in greater stability of the product. Also, the pre-exponential factor, $k_{o}$, was also calculated and is equal to $4.034 \times 10^{16} \mathrm{~d}^{-1}$ which is theoretically the rate constant as the temperature approaches infinity.

In addition to Arrhenius parameters, the $Q_{10}$ may be determined. At a given temperature, it is defined as the ratio of the rate constants when the temperature is increased by $10^{\circ} \mathrm{C}$, or the factor of change in shelf-life, $t_{s}$, when the food is stored at a temperature $10^{\circ} \mathrm{C}$ higher (Taoukis et al., 1997). It also describes the sensitivity of the rate of a reaction to temperature. It may be expressed in the Arrhenius equation such that

$$
\ln Q_{10}=-\frac{E_{a}}{R}\left(\frac{1}{T}-\frac{1}{T+10^{\circ} \mathrm{C}}\right)
$$

Where the temperature should be absolute and expressed in Kelvin. Assuming the room temperature is equal to $27.7^{\circ} \mathrm{C}(300.85 \mathrm{~K})$, the value of $Q_{10}$ at room temperature is, therefore, equal to 3.90. This value of $Q_{10}$ for NEB of batuan fruit powder is near to 2.2-3.5 for cheese powder (Kilic et al., 1997) and 2-3 at temperature above $30^{\circ} \mathrm{C}$ for condensed milk (Patel et al., 2007). Moreover, the type of NEB for the product could be Maillard reaction which primarily occurs in dehydrated or semi-moist foods during storage (Saltmarch and Labuza, 1982).

Therefore, the obtained values of activation energy and $Q_{10}$ for batuan fruit powder are comparable to the typical activation energy and $Q_{10}$ for a Maillard reaction in food powders which are around $100 \mathrm{~kJ} \mathrm{~mol}^{-1}$ and 3, respectively (Bhandari et al., 2013). This high value activation energy indicates that Maillard browning is highly sensitive to temperature change. On the other hand, the $Q_{10}$ of 3 means that the rate of Maillard reaction increases 3 times when the temperature is increased by $10^{\circ} \mathrm{C}$.

\subsection{Prediction of shelf-life of batuan fruit powder}

The shelf-life of batuan fruit powder, based on WI, may be estimated based on the kinetics of NEB at high temperatures. However, an unexpected behavior was observed such that equilibrium WI was achieved for each temperature. It was not possible to predict the equilibrium value at room temperature because at room temperature, there was no significant difference between the values of color of the powder. Thus, the equilibrium WI and critical WI remained unknown to be able to compute for the shelf-life. Because of the very slow rate of change in WI at lower temperature, the values were interpreted as not significantly different. Nevertheless, the true behavior of the curve may have been investigated had only the duration of the storage at lower temperature was further lengthened.

The product is practically stable at room temperature because of $\mathrm{MC}(0.1204 \mathrm{~g}$ water $/ \mathrm{g}$ solids $)$ near the monolayer value $(0.0850 \mathrm{~g}$ water $/ \mathrm{g}$ solids, determined from a preliminary experiment), very low $\mathrm{pH}$ (1.58), small amount of substrates (i.e., reducing sugar, protein, oxygen in the headspace) that limit the rate of NEB, and excellent packaging material (metallic foil) that practically did not allow transmission of water vaplor or air through the film. However, at higher temperatures, aside from increased rate of browning, the product may also undergo agglomeration and caking due to transition of the state from glassy to rubbery (not because of moisture absorption but a result of heat absorption of the product).

However, it would still be possible to calculate shelflife even with the limitations of the kinetic equations (Lee and Krotchta, 2002). In order to predict the shelf- 
life of the batuan fruit powder at room temperature (assumed to be $27.7^{\circ} \mathrm{C}$ ), the rate constants at high temperatures and room temperature, and shelf-life values at high temperatures were determined. Then, using Equation 2, the shelf-life at room temperature was calculated. Similarly, given the latter equation, the Arrhenius model may also be expressed in terms of shelf -life values at 2 temperatures.

$$
\ln \frac{t_{s 1}}{t_{s 2}}=\frac{E_{a}}{R}\left(\frac{1}{T_{1}}-\frac{1}{T_{2}}\right)
$$

In determining the shelf-life at $37^{\circ} \mathrm{C}, 50^{\circ} \mathrm{C}$, and $60^{\circ}$ $\mathrm{C}$, the results of the quality scoring by the panelists with respect to general acceptability was considered because the general acceptability already accounted all possible sensory attributes (i.e., color, aroma, off-odor, caking, stickiness) for the panelists to decide whether the product is acceptable or not.

To apply the latter equation, the shelf-life at high temperature must be determined. The first consideration in selecting the shelf-life for each high temperature was if the sample at a certain sampling time was already significantly different in terms of general acceptability (Table 1) from the initial. At $37^{\circ} \mathrm{C}$, no significant difference was found between the scores from 0 to 20 days. At $50^{\circ} \mathrm{C}$, there was already a significant difference between the sample at $t=0$ and $t=12 \mathrm{~d}$. At $60^{\circ} \mathrm{C}$, the sample at $t=3 \mathrm{~d}$ was already different from that at $t=0$. Another criterion was to look for the "critical" time at which the score was 5 (slightly acceptable) such that below this score, the product was already unacceptable. For temperatures $37^{\circ} \mathrm{C}$ and $50^{\circ} \mathrm{C}$, the scores were still above 5 meaning the product was still acceptable to the panelists for the whole duration of sampling. However, at $60^{\circ} \mathrm{C}$, the product was already unacceptable (score less than 5) after 3 days so that the "critical" time (to get a score of 5 at the time somewhere between 0 and 3 days), was failed to be observed. Therefore, the basis for the shelf-life would only be the time where the sample was already significantly different from the initial, which was observed only at $50^{\circ} \mathrm{C}$. Hence, the shelf-life used for batuan fruit powder at high temperature was 12 days at $50^{\circ} \mathrm{C}$.

Using the Arrhenius equation, the rate constant at $27.7^{\circ} \mathrm{C}$ was extrapolated to be $0.01689 \mathrm{~d}^{-1}$. On the other hand, the rate constant at $50^{\circ} \mathrm{C}$ is equal to $0.2846 \mathrm{~d}^{-1}$. Hence, the shelf-life at room temperature was computed to be 202 days which is equivalent to 6 months 22 days, based mainly on NEB (in terms of WI) of the dried, powder sample.

\section{Conflict of interest}

The authors would like to declare that they have no conflict of interest.

\section{Acknowledgement}

The authors would like to acknowledge the Science Education Institute, Department of Science and Technology (DOST-SEI) and the Bureau of Agricultural Research, Department of Agriculture (DA-BAR) for the research funding, and the faculty and staff of Institute of Food Science and Technology, CAFS, UPLB, for the use of facilities.

\section{References}

Association of Official Analytical Chemists (AOAC). (2000). Official Methods of Analysis. $17^{\text {th }}$ ed. Washington, DC, USA: Association of Analytical Chemists, Inc.

Average Temperatures in Manila, Luzon, Philippines (2015). Manila, Philippines: ClimaTemps.com. Retrieved on June 14, 2019 from ClimaTemps Website: www.manila.climatemps.com/ temperatures.php

Bainto, L.C., Dizon, E.I. and Castillo-Israel, K.A.T. (2018). Effects of various methods on hydroxycitric acid content of "batuan" [Garcinia binucao (Blanco) Choisy] fruits. International Food Research Journal, 25(1), 13-19.

Bawar, R.A. (2013). Effects of Different Pre-Heat Treatments and Drying Temperatures on the Physico -Chemical and Antioxidant Characteristics of Mango (Mangifera indica L.) Kernel Flour. Laguna, Philippines: University of the Philippines Los Baños, MS Thesis.

Berlinet, C., Brat, P., Brillouet, J.M. and Ducruet, V. (2006). Ascorbic acid, aroma compounds and browning of orange juices related to PET packaging materials and $\mathrm{pH}$. Journal of the Science and Food Agriculture, 86(13), 2206-2212. https:// doi.org/10.1002/jsfa.2597

Bhandari, B., Bansal, N., Zheng, M. and Schuck, P. (2013). Handbook of Food Powders: Processes and Properties. Cambridge, UK: Woodhead Publishing Limited. https://doi.org/10.1533/9780857098672

Buedo, A.P., Elustondo, M.P. and Urbicain, M.J. (2000). Non-enzymatic browning of peach juice concentrate during storage. Innovative Food Science and Emerging Technologies, 1(4), 255-260. https:// doi.org/10.1016/S1466-8564(00)00031-X

Burdurlu, H.S. and Karadeniz, F. (2003). Effect of storage on nonenzymatic browning of apple juice 
concentrates. Food Chemistry, 80(1), 91-97. https:// doi.org/10.1016/S0308-8146(02)00245-5

Chang, L.S., Karim, R., Abdulkarim, S.M., Yusof, Y.A. and Ghazali, H.M. (2018). Storage stability, color kinetics and morphology of spray-dried soursop (Annona muricata L.) powder: Effect of anticaking agents. International Journal of Food Properties, 21 (1), 1937-1954.

doi.org/10.1080/10942912.2018.1510836

Chang, L.S., Karim, R., Abdulkarim, S.M., Chai, K.F. and Ghazali, H.M. (2019). Moisture sorption isotherm and shelf-life prediction of anticaking agent incorporated spray-dried soursop (Annona muricata L.) powder. Journal of Food Process Engineering, e13134. https://doi.org/10.1111/ jfpe. 13134

Chu, N.T. and Clydesdale, F.M. (1976). Decomposition of organic acids during processing and storage. Journal of Milk and Food Technology, 39(7), 477480. https://doi.org/10.4315/0022-2747-39.7.477

Damasceno, L.F., Fernandez, F.A.N., Magalhaes, M.M.A. and Brito, E.S. (2008). Evaluation and optimization of nonenzymatic browning of cajuina during thermal treatment. Brazilian Journal of Chemical Engineering, 25(2), 313-320. https:// doi.org/10.1590/S0104-66322008000200010

Dursun, A., Guler, Z. and Sekerli, Y.E. (2017). Characterization of volatile compounds and organic acids in ultra-high-temperature milk packaged in tetra brik cartons. International Journal of Food Properties, 20(7), 1511-1521. https:// doi.org/10.1080/10942912.2016.1213280

Ebert, A.W. (2014). Potential of underutilized traditional vegetables and legume crops to contribute to food and nutritional security, income and more sustainable production systems. Sustainability, 6(1), 319-335. https://doi.org/10.3390/su6010319

Florido, H.B. and Cortiguerra, F.F. (2003). Lesser known edible tree species. Research Information Series on Ecosystems, 15(3), 1-8.

Fraeye, I., de Roeck, A., Duvettr, T., Verlent, I., Hendrickx, M. and Van Loey, A. (2007). Influence of pectin properties and processing conditions on thermal pectin degradation. Food Chemistry, 105(2), 555-563.

https://doi.org/10.1016/

j.foodchem.2007.04.009

Hsu, C.L., Chen, W., Weng, Y.M. and Tseng, C.Y. (2003). Chemical composition, physical properties, and antioxidant activities of yam flours as affected by different drying methods. Food Chemistry, 83(1), 85-92. https://doi.org/10.1016/S0308-8146(03) 00053-0
Hui, Y.H. (Ed). (2008). Handbook of Fruits and Fruit Processing. NY, USA: John Wiley and Sons.

Ibarz, A., Pagan, J. and Garza, S. (2000). Kinetic models of non-enzymatic browning in apple purée. Journal of the Science of Food and Agriculture, 80(8), 11621168. https://doi.org/10.1002/1097-0010(200006) 80:8<1162::AID-JSFA613>3.0.CO;2-Z

Jaya, S. and Das, H. (2005). Accelerated storage, shelf life and color of mango powder. Journal of Food Processing and Preservation, 29(1), 45-62. https:// doi.org/10.1111/j.1745-4549.2005.00012.x

Kilic, M., Muthukumarappan, K. and Gunasekaran, S. (1997). Kinetics of nonenzymatic browning in cheddar cheese powder during storage. Journal of Food Processing and Preservation, 21(5), 379-393. https://doi.org/10.1111/j.1745-4549.1997.tb00791.x

Koca, N., Burdurlu, H.S. and Karadeniz, F. (2003). Kinetics of nonenzymatic browning reaction in citrus juice concentrates during storage. Turkish Journal of Agriculture and Forestry, 27(6), 353-360.

Lee, K.G. and Shibamoto, T. (2002). Toxicology and antioxidant activities of non-enzymatic browning reaction products: Review. Food Reviews International, 18(2-3), 151-175. https:// doi.org/10.1081/FRI-120014356

Lee, S.Y. and Krotchta, J.M. (2002). Accelerated shelf life testing of whey-protein-coated peanuts analyzed by static headspace gas chromatography. Journal of Agricultural and Food Chemistry, 50(7), 2022-2028. https://doi.org/10.1021/jf010501j

Mojica, M.J.J. (2008). Farmers in Zambales gain from sweet tamarind. BAR Chronicle: A Monthly Publication of the Bureau of Agricultural Research 9 (2). Retrieved on September 1, 2014 from the BAR Website: www.bar.gov.ph

Muzaffar, K. and Kumar, P. (2017). Quality assessment and shelf life prediction of spray-dried tamarind pulp powder in accelerated environment using twodifferent packaging materials. Journal of Food Measurement and Characterization, 11(1), 265-271. https://doi.org/10.1007/s11694-016-9393-1

Patel, A.A., Gandhi, H., Singh, S. and Patil, G.R. (2007). Shelf-life modelling of sweetened condensed milk based on kinetics of Maillard browning. Journal of Food Processing and Preservation, 20(6), 431-451. https://doi.org/10.1111/j.1745-4549.1996.tb00758.x

Quevedo, E.S., Dizon, E.I. and Merca, F.E. (2017). Organic acid profile of "batuan" [Garcinia binucao (Blco.) Choisy] fruit. Annals of Tropical Research, 39(2), 25-33. https://doi.org/10.32945/atr3923.2017

Quevedo, E.S., Laurena, A.C. and Merca, F.E. (2013). Physicochemical properties, nutritional and sensory 
quality of "batuan" [Garcinia binucao (Blco.) Choisy] fruits. Annals of Tropical Research, 35(2), 1 -21. https://doi.org/10.32945/atr3521.2013

Reyes, F.K. (2000). Sweet tamarind propagation and management. In BAR Research and Development Digest (Official quarterly publication of the Bureau of Agricultural Research) July-September 2000 2(3). Retrieved on September 1, 2014 from the BAR Website: $\quad$ www.bar.gov.ph/digest-home/digestarchives/135-2000-3rd-quarter/3436-july-sep2000sweet-tamarind-propagation-and-management

Saltmarch, M. and Labuza, T.P. (1982). Nonenzymatic browning via the Maillard reaction in foods. Diabetes, 31(Supplement 3), 29-36. https:// doi.org/10.2337/diab.31.3.S29

Sanchez, D. (2012). Powdered Calamansi Anyone? In The Philippine Star December 16, 2012 Issue. Retrieved on July 3, 2019 from The Philippine Star Website: www.philstar.com/business/ agriculture/2012/12/16/886373/powdered-calamansianyone

Sheen, L.Y. (1990). Studies of microcapsules of essential oils of basil, garlic, and ginger. Taichung, Taiwan National Chung-Hsing University, PhD Dissertation.

Taoukis, P.S., Labuza, T.P. and Saguy, I.S. (1997). Kinetics of Food Deterioration and Shelf-life Prediction. In Valentas, K.J., Rotstein, E. and Singh, R.P. (Eds). Handbook of Food Engineering Practice, p. 361-403. NY, USA: CRC Press.

Tsai, L.J. (1994). Research and development of extrudates containing porcine blood. Taiwan: National Taiwan University, MS Thesis.

Valdramidis, V.P., Cullen, P.J., Tiwari, B.K. and O'Donell, C.O. (2009). Quantitative modeling approaches for ascorbic acid degradation and nonenzymatic browning of orange juice during ultrasound processing. Journal of Food Engineering, 96(3), 449-454. https://doi.org/10.1016/ j.jfoodeng.2009.08.025

Valencia, C. (2013a). Crop Consolidator Seeks More Tamarind Suppliers. In The Philippine Star August 28, 2013 Issue. Retrieved on September 1, 2013 from The Philippine Star Website: www.philstar.com/business/2013/08/28/1141711/ crop-consolidator-seeks-more-tamarind-suppliers

Valencia, C. (2013b). Palawan's Endemic Fruits Eyed for Export. In: The Philippine Star February 3, 2013 Issue. Retrieved on August 13, 2014 from The Philippine Star Website: http://www.philstar.com/ agriculture/2013/02/03/904088/palawans-endemicfruits-eyed-export

Wang, H., Hu, X., Chen, F., Wu, J., Zhang, Z., Liao, X. and Wang, Z. (2005). Kinetic analysis of nonenzymatic browning in carrot juice concentrate during storage. European Food Research and Technology, 223(2), 282-289. https:// doi.org/10.1007/s00217-005-0202-z

World Health Organization (WHO). 1999. Safety Evaluation of Certain Food Additives. Retrieved on June 17, 2019 from the WHO Website: www.inchem.org 